\title{
DEVELOPING AN E-BOOK BASED INTRODUCTION TO ECONOMICS LEARNING MATERIALS USING ALDIKO CLASSIC APPLICATION FOR SOCIAL SCIENCES STUDENTS
}

\author{
By \\ Lailatul Rofiah', Wafiyatu Maslahah ${ }^{2}$ \\ ${ }^{1}$ Faculty of Education, Universitas Islam Raden Rahmat Malang \\ ${ }^{2}$ Faculty of Education, Universitas Islam Raden Rahmat Malang \\ Email: ${ }^{1}$ lailatulrofiah14@gmail.com
}

\section{Article Info \\ Article History: \\ Received:12-10-21 \\ Revised : 14-11-21 \\ Accepted: 21-11-2021}

\section{Keywords: \\ Learning Material \\ E-book}

Aldiko Classic

\begin{abstract}
This research has a long-term purpose: to implement the study of introduction to economics effectively and efficiently. The learning materials developed were the non-printing type using the Aldiko Classic application so that the students do not have to spend more money to buy the printed learning material.The students just have to download the application (for free) in Playstore and install the learning materials of introduction to economics developed in such application.It was expected that the social sciences education students better understand the learning materials taught by the lecturer using the e-bookand ease them to study independently. The stages in developing the e-book based learning material are as follows: 1.) analysis stage (analysis) covers the analysis of learning sources and learning material requirement, 2.)design stage (design) is to determine the learning material framework, cover learning material, layout, references, and creating assessment instrument of learning material, 3.) Development stage (Development) covers developing an e-book based learning material, experts validation and revision,4.) implementation stage (implementation) is the trial test of learning material which has been validated, 5) Evaluation stage (Evaluation) is the stage to analyze weakness and strength of learning material which has been tested to students. The research results are 1) the development of an e-book based introduction to economics learning material has excellent feasibility because it has been conducted validation with an average score of $83 \%$ (valid). 2) the learning material of e-book based introduction to economics was declared practical to be used by the students based on the results of the response questionnaire with an average score of $77 \%$ (practical).
\end{abstract}

This is an open-access article under the CC BY-SA license.

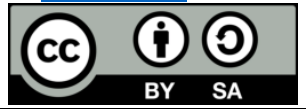

Corresponding Author:

Lailatul Rofiah,

Social Sciences Education, Faculty of Education

Universitas Islam Raden Rahmat Malang,

Email: lailatulrofiah14@gmail.com

\section{INTRODUCTION}

In the modernization age these days, humankind is very dependent on technology. This dependency makes technology become anessential requirement for everyone. In the education discipline, technology has a unique role in the learning-teaching process. The global demand urges the education discipline to continuously and constantly adjust to technological development to enhance educational quality, mainly in the adjustment in employing information and communication technology for education, particularly in the learning process.

The positive impact attained from technological development occurred in the education is that the student can search and find various information and knowledge swiftly through internet network[1]. So, in its development, the technology developed rapidly, and it was accompanied by the emergence of application that was easy to be studied and utilized in learning media. With easyaccess to technological development through the internet network, knowledge is easy to access and disseminate. A Learning media is an obligatory element that must be existed in the 
learning process, one of which is learning material.Learning material is a crucial part of the overall learning process [2]. Learning material is a critical element in learning activity because it contains a material grid or beacons about to be taught. Without learning material, a lecturer cannot interact effectively with the students. Hence, it is necessary to develop the learning material utilizing technology to proceed effectively and efficiently. The development of science and technology affects the way teenagers view using the Internet as a primary goal. This development is also changing the paradigm of learning in education. On its Website, UNESCO has said thatinformation and communication technology (ICT) can contribute to the freedom of access to education, equality ineducation, delivering learning quality, and teaching.[3].

In developing the learning material, one must answer or solve the problems or difficulties in the studying process. Some learning materials in which the students had difficulties understanding it, or the lecturer would have had tough times explaining it. Such difficulties could have occurred because the materials were abstract, complicated, strange, and et cetera. To overcome thesedifficulties, it needs to develop suitable learning material. If the learning materials about to teach were abstract, the learning materials must help students describe those abstract matters, for instance, by employing figures, photographs, charts, schemes, et cetera. Similarly to the complex materials, it should be explained thoroughly, corresponding to the degree of students' thoughts, that it becomes easier to understand [4]

The phenomenon or problem that the researcher often met in the learning process is that some students who ignored the lecturer when he teaches were looking down most of the time to see their handphones/smartphones. So, instead of using their smartphones for useless purposes, it is better to use their devices to support their study. Many students who did not have or brought their reference book or textbook make many unreasonable excuses; for instance, if they brought the book, their bag would be heavy or did not fit in their bag, some students also said they could not afford to buy the textbook because of the high price or the distance to buy the book was far away.

One of the ways to overcome those problems is by developing the learning material used in teachinglearning activities. One suitable learning material that does not need much money to develop is the non-printed ebook-based learning material using the Aldiko Classic application. Currently, the e-book realm has become a trend and ease writers to disseminate their writings quickly and simply. Using its technical thought, we can imagine if the e-book does not need substantial cost as in the printed textbook. Based on the described exploration, the researchers want to develop learning material of an e-book-based introduction to economics so that the learning can proceed more effectively and efficiently.

\section{RESEARCH METHOD}

This study is a research and development type (R\&D). According to Sugiyono, the R\&D research method generates a specific product and tests its effectiveness. The R\&D research in education is a process used to develop and determine the validity of a product $[5,6]$. Hence, the development research conducted by the researchers was to design a product in the form of learning material of e-book-based introduction to economics using Aldiko Classic application and then carried out validation to the product. The experts conducted the product validation to the media and learning materials. Subsequently, the product was tested on the Social Sciences education students to determine the product's feasibility and practicality of such learning material so that the product was taken as the learning source for the Social Sciences education students.

The following figure is the research and development design conducted in this study by employing ADDIE as follows:

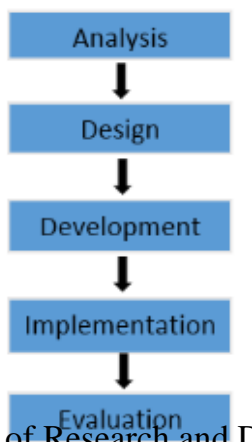

Figure 2.1 The model of Research and Development using ADDIE

As for the details of every stage in developing the learning material for the e-book-based introduction to economics by employing the ADDIE model is as follows:

1. Analysis Stages 
International Journal of Social Science (IJSS)

Vol.1 Issue.4 December 2021, pp: 355-360

ISSN: 2798-3463 (Printed) | 2798-4079 (Online)

This stage was conducted to analyze the relevance in developing the learning material, among others, the analysis of learning sources requirement that it was expected the developed learning material can be used as the learning sources for the students, particularly the Social Sciences education students. Afterward, it was conducted material analysis, and the activity was carried out to arrange material and describe the primary materials of introduction to economics based on the Lesson Plan made by the lecturer

2. Design Stages

This stage was conducted to design the writings of learning materials based on the analysis stage result, including the layout of learning material, deciding the references, and making assessment instrument of learning material

3. Development stage

This stage is to realize the layout of learning material, in this stage also conducted validation and revision of the learning material

4. Implementation Stage

This stage is the trial test stage in which the product has been validated and revised

5. Evaluation Stage

This stage is to analyze the weaknesses and strengths of the learning material

This research aims to determine the feasibility or validity of the e-book-based introduction to economics learning material and the practicality of introduction to economics learning material for the Social Sciences education students [7-10].As for the validity category and practicality category for the learning material will be described in the following tables:

Table2.1 Validity Criteria

\begin{tabular}{|c|c|c|}
\hline No & Validity Criteria & Validity Level \\
\hline 1 & $85.01 \%-100.00 \%$ & Extremely Valid \\
\hline 2 & $70.01 \%-85.00 \%$ & Valid \\
\hline 3 & $50.01 \%-70.00 \%$ & Less Valid \\
\hline 4 & $01.00 \%-50.00 \%$ & Not Valid \\
\hline
\end{tabular}

Table 2.2 Product Practicality Criteria

\begin{tabular}{|c|c|c|}
\hline No & Practicality Criteria & Practicality Level \\
\hline 1 & $81.00 \%-100.00 \%$ & Extremely Practical \\
\hline 2 & $61.00 \%-80.00 \%$ & Practical \\
\hline 3 & $41.00 \%-60.00 \%$ & Less Practical \\
\hline 4 & $21.00 \%-40.00 \%$ & Not Practical \\
\hline 5 & $00.00 \%-20.00 \%$ & Extremely Not Practical \\
\hline
\end{tabular}

\section{RESULTS AND ANALYSIS}

3.1. Developing an e-book-based introduction to economics learning material using Aldiko Classic application for Social Sciences education students

The e-book-based introduction to economics learning material using the Aldiko Classic application was developed using the Indonesian language. The learning material consists of the main page, the cover, preface, and 
table of content; the cover will appear on the front screen in the Aldiko Classic application, and subsequently, the content part consists of the conceptual maps and materials. These parts will be displayed as the following figures:

\section{Figure3.1 Learning Material on Aldiko Classic Application}
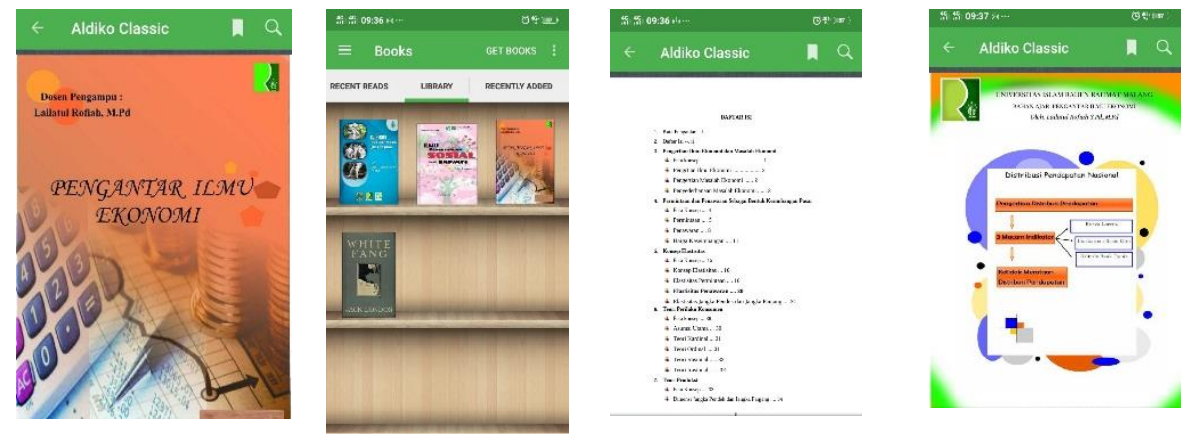

The learning materials developed can be observed in Figure 3.1, in which it has been conducted validity test by the validator, experts in media, and learning materials. The average result of the learning material's validity or feasibility score which has been developed is $83 \%$; as a result, the writers conclude that the e-book-based learning material of introduction to economics by applying Aldiko Classic application was feasible

\subsection{The Practicality of the E-Book-Based Introduction to Economics Learning Material by Applying Aldiko \\ Classic Application for Social Sciences education students}

The practicality of the e-book-based introduction to economics learning material was developed based on the students' questionnaire responses. The practicality of such learning material was reviewed from three aspects, namely, easiness to use, attraction, and efficiency. Afterward, the result of the student questionnaire obtained was categorized conforming to the practicality according to Akbar[10]. The calculation result of the practicality percentage of the learning material is presented in the following table:

Table 3.1 Percentage of Learning Material Practicality

\begin{tabular}{|c|l|c|c|c|c|}
\hline No & \multicolumn{1}{|c|}{ Aspect } & Tse & Tsh & Percentage & Criteria \\
\hline $\mathbf{1}$ & Easiness to Use & $\mathbf{3 , 2 5}$ & $\mathbf{4}$ & $\mathbf{8 1 , 2 5 \%}$ & $\begin{array}{c}\text { Extremely } \\
\text { Practical }\end{array}$ \\
\hline $\mathbf{2}$ & Attraction & $\mathbf{2 , 9 9}$ & $\mathbf{4}$ & $\mathbf{7 5 \%}$ & Practical \\
\hline $\mathbf{3}$ & Eficiency & $\mathbf{3 , 0 0}$ & $\mathbf{4}$ & $\mathbf{7 5 \%}$ & Practical \\
\hline \multicolumn{2}{|c|}{ Average } & $\mathbf{3 , 0 8}$ & & $\mathbf{7 7 \%}$ & Practical \\
\hline
\end{tabular}

Based on the three aspects above, it was obtained an average score of $77 \%$. Therefore, it can be concluded that the e-book-based learning material using the Aldiko Classic application developed was pretty practical to be used by the Social Sciences education students.

\section{CONCLUSION}

Based on the research result conducted, the writers conclude that in developing learning material of an ebook-based introduction to economics using Aldiko Classic application, the average score was $83 \%$, and it has excellent validity or feasibility. Because an e-book-based introduction to economics learning material has been validated by the learning material and media experts, as for the practicality level of the learning material of an ebook-based introduction to economics was in the average of $77 \%$ score. Therefore, it can be deduced that the learning material of an e-book-based introduction to economics developed by the writers was practical to use.

\section{ACKNOWLEDGEMENTS}

The writers would like to give sincere gratitude to the learning material validator expert and material validator expert who are willing to spare their time to validate the learning material in this study. Furthermore, the writers would like to give sincere gratitude to the Faculty of Education, particularly the Social Sciences education study program that supports and provides aid to this research. Without support from many parties, this research would not be run as planned and successfully. 
International Journal of Social Science (IJSS)

Vol.1 Issue.4 December 2021, pp: 355-360

ISSN: 2798-3463 (Printed) | 2798-4079 (Online)

Crossref DOI: https://doi.org/10.53625/ijss.v1i4.714

\section{REFERENCES}

[1] Abdulkarim et al. "Developing civicpedia as civic an education E-Learning Media to improve students information literacy ” Journal of Social Studies Research Vol 9, No. 3, pp 45-61. 2018

[2] Ramdani, Yani. Pengembangan Instrumen dan Bahan Ajar Untuk Meningkatkan Kemampuan Komunikasi, Penalaran, dan Koneksi Matematis Dalam Konsep Integral. Jurnal Penelitian Pendidikan. 13 (1): 14-52.2012

[3] Ahmar, Ansari and Rahman, Abdul, "Development of Teaching Material Using an Android" Global Journal of Engineering Education, Vol 19, No 1, pp. 72-76, February 2017

[4] Erah, Siti Syarah, et al. Pengembangan Bahan Ajar Non Cetak Berbasis Ebook Dengan Aplikasi Adobe Captivate 3.0 Untuk Kelas Viii Smp Negeri 1 Cilimus. Bachelor thesis, IAIN Syekh Nurjati Cirebon.2012

[5]Sugiono. Metode Penelitian Kuantitatif, Kualitatif dan R\&D. Bandung: Alfabeta.2011

[6]Sugiono. Metode Penelitian Kuantitatif, Kualitatif dan R\&D. Bandung: Alfabeta. 2014

[7] Nurul Zuriah and Naufal., "Development of PPkn Learning Media Based on Android” ICCD 2019. Vol 349, pp 410-414, October 2019

[8] Fahrurrozia, et al. "The Development of Android-Base Economic Teaching Materials for student independence" IJCC. Vol 5, pp 468-482. 2019

[9] Miarsyah Mieke et al., "MEBA: Development Android Base-Ecosystem Module For Senior High School Student" Indian Journal Of Public Health Research and Development. Vol 10 No.8, pp 2114-2118. August 2019

[10] Akbar, Instrumen Perangkat Pembelajaran. Bandung: PT Remaja Rosdakarya. 2013

[11] Creswell, John W.Research Design Pendekatan Kualitatif, Kuantitatif, dan Mixed. Yogyakarta. Pustaka Pelajar.2009

[12] Emzir.Metodologi Penelitian Kualitatif Analisis Data. Jakarta: Rajawali Press. 2011

[13] Haris, D. Panduan Lengkap E-book: Strategi Pembuatan dan Pemasaran E-book. Yogyakarta: Cakrawala. 2011

[14] Lestari, I.. Pengembangan Bahan Ajar Berbasis Kompetensi (Sesuai dengan Kurikulum Tingkat Satuan Pendidikan). Padang: Akademia Permata. 2013

[15] Prastowo, A.. Panduan Kreatif Membuat Bahan Ajar Inovatif. Yogyakarta: Diva Press. 2012

[16] Rahmawati, et al. Pengembangan bahan ajar ebook pada mata pelajaran praktikum akuntansi lembaga berbasis kontekstual untuk SMK. Jurnal Pendidikan Akuntansi. 7(3): 383-391 2019

[17]Riduwan \& Akdon. Rumus dan Data Dalam Statistika. Bandung. Alfabeta. 2007

[18] Widodo \& Jasmadi.Panduan Menyusun Bahan Ajar Berbasis Kompetensi. Jakarta: PT Elex Media Komputindo.2008. 
